\title{
The Royal Navy under Charles I
}

\section{Part UI.—ThE AdmRistration.}

THE system, inangurated in 1618, of governing the navy by 1 commissioners acting under the lord high admiral remained in force until February 28, when the four principal officers resumed control under Backingham. Although the commissioners' direction was of course, both in ability and honesty, immeasurably superior to that of Mansell, they cennot be said to have risen to any great excellence of administration. In October 1627 Charles, in writing to the duke, apologised for the slowness with which supplies were furnished, ' the canse whereof is . . . the slow proceedings of the commissioners of the navy (which all commissioners are liable to).' ${ }^{\prime}$ If king and minister were both of this opinion, it would account for the supersession which so soon followed. After Buckingham's murder the post of lord high admiral was put into commission, and the new lords of the admiralty were even more reliant on the capacity of the principal officers than had been their predecessors; but they appear to have been also more suspicious of them than the commissioners were. Of Buckingham it may be said that, had he possessed less power, be would have made a better chief. In the ten years he held office he practically doubled the effective of the navy, for the commissioners could have done little without his aid. So far as the emptiness of. the treasury would allow ho enlurged and repaired docks and storehouses, and, if he did not discover, he was one of the first to appreciate the naval importance of Portsmouth.' He provided for the home manufacture of cordage by inducing Datchmen to settle here and teach Englishmen their art, and was the builder of the first ropohouses attached to English dockyards. He reintroduced lieutenants and corporals on bosrd ship, and was the first administrator who began systematic naval and gannery instruction in the service.

' Halliwell's Royal Latters, ii. 277.

2 Portsmouth was largely used during the earlier years of the reign of Henry VIII, bat lost its pre-eminence when Deptford, Woolwioh, and Chatham were founded. It is carions that one of the flrt reoognitions of its value as a permsnent neval station ghould heve come trom Phllip II (Stato Papers, Domestic, Mary; vi. 16). 
Unfortunately for his memory, he must be judged not as head of the navy but as the all-powerfal minister, and in that sense history has pronounced its verdict. ${ }^{3}$

Since 1618 the duties of the treasurer of the navy had become, and remained in the future, almost entirely financial. His salary was increased from 1630 by the grant of the poundage of threepence on all payments made by him, including wages, instead of, as before, only on those to merchants supplying stores, as well as a house at Deptford and other advantages, and in 1634 his fixed fee was raised from $270 l .138 .4 d$. to $645 l .138 .4 d .^{4}$ He even receired the poundage on the salaries of the other three officers, and they were continually petitioning for an advance in their rate of pay, which had remained unaltered since their posts were created by Henry VIII. It is suggestive to find that, anong their reasons for the requested increase, they mention that before the reforms of 1618 they had an allowance of $60 l$. a year from the treasurer and victualler for passing their accounts, ${ }^{8}$ and that the surveyor and comptroller estimated the total annual value of their perquisites before that date at $384 l$. and $430 l$. respectively. This included the allowance from the treasurer and victaaller, commissions given by officers on appointment, and dividends divided among them from the sale of old stores. ${ }^{6}$ In 1637 they appear to have been promised that if they could obtain their augmentation without going to the royal coffers for it they were welcome to whatever they could get. Accordingly they point out that in this year they had prevented fraudalent overcharge on the part of owners of hired merchantmen to the extent of $1,374 l$, and they therefore desired to divide the whole of this sum. ${ }^{7}$ What advantage this would be to the crown they omitted to say. They were exceptionally unlucky, seeing that most officials had only to petition in order to receive. In one case 20l. a year was taken off the salaries of the masters attendant, but, when these complained, they had each $40 l$. a year added and with less work. Their ill fortune was, perhaps, due to the disfavour with which the lords of the admiralty seem to have usually viewed them, and it was not until the era of the long parliament, when, from motives of fear, all wages were raised, that they shared in the general increase. None of these officers was of any historic interest.

It is diffedt to apportion the credit for the reforms which followed 1618 between the commissioners and Backingham. Nicholas (Stato Papers, Domestic, Charles $I$, corli. 85,86 ) gives it to Buclengham ; bat Nicholas was his private searetary, and wo know that the duke hed no grasp of detail. 'On the other hand he wrote atter the dake's death, when he had nothing more to hope trom him, end it is certain that the commissioners conld not have atood for twenty-four hours against the vested interests they attacked without Buckingham's congistent support.

Add. MS8. 9901, t. 110. - State Papers, Domestic, Charles I, cosiv. 9.

- State Papers, Domostic, Elieabeth, ccrrrvii. 1. 188.

- Stato Papers, Domestic, Oharles I, ceclrxii. 21. 
For two and a half years, between 1627 and 1629, Sir Sackville Crowe was treasurer, but he, to put as favourable a construction as possible on what happened, got bis accounts into confusion to the extent of 1,500l.8 Before and after Crowe Sir Wm. Russell wass sole treasurer till 1699, then for two years with the younger Vane, and again, in 1642, by himself till Auguat, after which Vane alone was reappointed. Russell was a mere man of affairs, who confined himself to. his accounts, and seems never to have ventured an opinion on anything outside them. Kenrick Edisbury, at first paymaster, and from December 1632 surveyor of the navy, and perhaps the most observant and energetic of the chief officers, held the latter post till his death in 1638, when he was succeeded by Wm. Batten, who was appointed 'during pleasure,' instead of by patent for life, as in preceding cases. ${ }^{9}$ Sir Guilford Slingsby had been comptroller of the navy under Mansell, and was again given the same office in February 1628 by Charles. The main incidents of his second tenure which have come down to as relate to his assaults on his inferiors and his quarrels with his brother officers. Immediately after his appointment John Wells, the storekeeper of the navy, petitioned that, although the other officers had allotted him lodgings in the navy office, Slingsby, to accommodate his family and servants, 'hath violently taken his lodgings from him.' ${ }^{10}$ In 1629 his colleagues complained to the lords commissioners that he had felled with a pocket pistol, and otherwise maltreated, the man in cherge of the navy office, and kept him out of the house, notwithstanding their wish to reinstate him. ${ }^{11}$ Slingsby died in 1632, and Sir H. Palmer succeoded him. The most notable event in Palmer's official career was his excuse for selling government cordage and pocketing the proceods - ' because his predecessors had done the like.' He subsequently amended this defence by saying that he had spent the money on neval necessaries. ${ }^{13}$ Till 1628 William Burrell was in charge of all ship-building and repairs, and in 1629 Burrell and Phin. Pett were made assistants to the principal officers. Burrell died in 1630, and from January 1631 Pett became himself a principal officer, being three months junior to Bir Kenelm Digby, who had been appointed in the previous October. Neither

- It will be remembared that daring his treasurership he helped himself to $8,000 t$. from the Chatham chest, and that the money was still oring in 1644. After his dirmiseal from office Crowe was ambassador of the Levent Company at Constantinople, and, in 1646, nesrly ruined that company by, on the one hand, quarrelling with the Porte, and on the other imprisoning the members and agents of the association. When ho returned in 1648 he was sent to the Tower, but seems to have escaped scatheleas.

- By an order of 13 Feb. 1687 no plece in the nafy or ordnanoe offloes was henceforth to be granted for life, but only during pleasure. Edisbury's real name was Willingon (Bee Hasted, History of Kent, i. 20 note, ed. Drake, London, 1886).

1- State Papsra, Domestic, Charlos $I$, cump. 87.

"Ibid. alii. $\mathbf{6 1 .}$

Idd. MB8. 9801, II. 121, 188. 
Digby nor Pett had any defined duties, and in Digby's case the position seems to have been almost entirely honorary, although at one time he was treating with Mervyn for the latter's command in the Channel. Mervyn asked 5,000l., his arrears of pay, to his rights in which Digby would presumably succeed, and the $3,000 l$. he had given for his admiralship of the narrow seas. ${ }^{18}$ It would be a matter of some interest to know to whom that $3,000 l$. was paid, but there had been obviously no secrecy in the transaction.

After Buckingham's death the lords commissioners met twice a week, sometimes at Wallingford House and sometimes in the council chamber at Whitehall. In April 1638 the child duke of York was made lord high admiral for life, and Northumberland his acting substitute during the king's pleasure; the navy, therefore, ceased to be governed by commission from that date. In 1628 the principal officers met at St. Martin's Lane, but in March 1680 some rooms were taken for them in a house in Mincing Lane at a rental of $80 l$. a year. ${ }^{14}$ Thenceforward expenses incurred in relation to that house appear in many of the accounts; it cost $150 l$. for furnishing, twelve months' beer there $19 l .88 .{ }^{15}$ yearly water rate $1 l$. 68. $8 d$., but only 38 . $6 d$. for Christmas gratuities. Although in 1628 the chief officers had been reinstated in a portion of their former authority, they by no means escaped the control of, and occasionally severe censure from, the lords of the admiralty. Sometimes my lords considered that their sympathies ran rather with their subordinates than with the king's interests, and, as most of them had been suspended for acts similar to those they were called upon to condemn in minor officials, the charge was not unfounded. ${ }^{16}$ In the fleet of 1637 embezzlement of stores by the boatswains had been very general. There was nothing unusual in this, but the resolve of the lords commissioners to punish the guilty persons appeared to strike the principal officers as both unusual and unfair. Their pleas on behalf of these men provoked the commissioners to write, "We observe that you are more apt to intercede for those that are most faulty than to certify what you find against other boatswains . . . . it is time by due punishment to break up this custom of the boatswains' exorbitant wasting of his majesty's stores, the continuance whereof so long with impunity hath, it seems, made the officers think it almost lewwul.' ${ }^{17}$ On another occasion they were told, 'If you were as careful of his majesty's service as

13 State Papers, Domestic, Charles $I$, clrniii. 6. Merrja to Nicholes.

it Add. MSS. 9297, L. 178 .

1) The price of beer at this time wag about $12,10 \mathrm{~s}$. a tun.

16 In 1694 Pelmer, the comptroller, Denis Fleming, clerk of tho scts, Phin. Pett, another principal officer, and several storekeepers and masters attendant had all bees suspended for selling gorernment stores for their ovn profit.

17 State Papers, Domrstic, Charles $I$, cocliii. 1. 88. 
you are to cast all such unfitting troubles on us, you would gain much more reputation and esteem to yourselves;' 18 and, once again, reference was made to their 'supine negligence.' While they were exposed to these snubs from their superiors one of their inferiors certainly, and others probsbly, expressed opinions of them with the same frankness. They complained to the lords that Francis Brooke, storekeeper at Portamouth, ' used many base words of ourselves, calling as loggerheads.' Perhaps the admiralty agreed with him; at any rate I do not find that Brooke was reprimanded, so that the only consolation left to them was their salaries.

Observers who acquitted the principal officers of intentional fraud accused them of incompetence, although they doubtless possessed the amount of intellect considered sufficient for permanent officials. They were seid not to know where their respective duties began or ended, but the conditions under which they worked were not favourable to success in management. Each one kept his books at his own residence, and neither sufficient time nor assistance was allowed for the various duties of inspection or bookkeeping which fell to him. Moreover they were compelled to purchase stores from persons holding patents for the sale of special articles, such as iron, canvas, \&c., a necessity sufficient to account for any depth of badness in the supply. Whether the confusion was due to neglect or overwork, the effect on the lower ranks of naval employés was the same. From the first year of the reign we have a continuous record of carelessness and frand, which neither commissioners nor lords commissioners seem to have been able to stamp out. In 1625, on board the ships at sea, pursers charged on the fall number of men supposed to be mustered and shared the profits made on those absent with their captains, while ganners and boatswains each lept from two to five servants who were rated as seamen, but who were boys and landsmen, and whose wages were retained by the officers. When the vessels were laid ap the ship-lieepers were usually drunk or absent. Captain Joshua Downing one night rowed down tho Medway, and 'might have gone on board all ships but three and done any mischief;' and 'in these twenty years last past all the navy hath not bred five able sailors nor two able gunners.' 19 Fifteen years later matters were as bad. John Holland, then paymaster of the navy, wrote that the ship-keepers and apprentice servants of the officers were coachmen, tailors, gardeners, \&c., and that the apprentices were dismissed at the end of their term as ignorant as when they joined.20 Robberies were frequent. "Genorally the

1 Stato Papers, Domestic, Charles $I$, cocliii. f. 55.

19 Ibid. xiii. 70, 1625, i.e. by the system of serrants and apprentices. It mas not until 1647 that the ship-keepers in the Medway were ordered to striko the bell on board everg half-hour through the night (Add. MSS. 9900, f. 108).

- Discourse of tho Nivy (Add. MSS. 9395). 
watchman is the thief and the ship-keeper the cabin-breaker ;' but the ship and dockyard officers dared not prosecute, because such a course would have called attention to their own delinquencies.21 Downing's cxperience did not evoke much attention, since, in the following year, it was reported from Chatham. 'There are divers that are upon the king's majesty's charges both for victuals and wages, but give no attendance nor do no service; neither can we take any muster of nny man but just at dinner time, for no longer than they are tied by the teeth are they to be kept on board,' this being in the full stress of war time. When captains were turning their men-of-war into cargo hoats, to enable merchants to defraud the customs, ${ }^{23}$ we need not be surprised that their inferior officers allowed themselves license in theft, and the references to carjanters, gunners, boatswrins, and pursers about the sale of stores entrusted to them are innumerable. That fortunes were made from 'chips' taken out of the dockyards is well known. 'The infinite abuse and prejudice the king has in all or most of his yards under colour of chips is intolerable;' ${ }^{24}$ again, ' a great quantity of wood is carried away by workmen when they go to breakfast, at dinner time, and at night under colour of, chips; they cut up good timber and call it chips;' 25 and in some yards the shipwrights built huts in which to store their plunder. In one case a lighter containing 8,000 tree-nails, said to be made from chips, but more probably stolen from Deptford yard, was seized, and the destined receiver was found to be one of the government shipwrights who also owned a private ship-building yard. Some of the dockyard employés converted the storehouses into lodgings for themselves and their families, and this abuse continued until the parliamentary nuvy committee made a clean sweep of them..$^{25}$

Of all the subordinate officials the pursers, as in later times, were the most acquisitive, having the greatest opportunities. Most places in the navy were for sale, but theirs were considered so profitable that they werc eagerly sought. In 1626 Nicholas was informed that a person, latcly mayor of Rochester, would give him 100l. for the appointment to the 'Anne Royal,' or 60l. for either of two others. As the ex-mayor could only sell again the eventual holder must have anticipated a handsome income. One article on which he made it was the beer; the brewer delivered this by beer measure, but the purser served it out by wine measure, pocketing the value of the difference. ${ }^{27}$ Sometimes he was a pluralist. One man was cook of the 'Bear' and purser of the 'George,' and ese-

21 Dicourse of the Navy (Add. Miss. 9435.)

I: Slate I'apers, Dentestic, Claarles I, xxvii. 60.

"Ibid. colx. 29. Edisbary to Nicholas.

Ibid. cli. 38 .

is Add. MSS. 0306, f, 119.

* Stale Papers, Domestic, Cilurles $T$, xxiii. 120, 1626. Ten scars later Yorthumberand made tho same complaint. 'Whe had been ro reform. 
cated both places by deputy. Of course they, like the others, sold their stores ashore. But one of their particular sources of profit was the men's clothes. In 1623 wearing apparel wess first ordered to be provided for the men, and to be sold to them at cost price, subject to a commission of one shilling in the pound for the purser. In 1628 it was being sold, when obtained, at 1 . 7 s. a suit, to be deducted from the wages, bat, as occurred with other naval requisites, the contractors frequently refused to supply it without prepayment. By 1636 the commissions had increased. The merchant had to pay two shillings in the pound for entering the clothes on board ; the paymaster and purser took each a further shilling on all articles sold, and of course the unfortunate sailor had to meet all these extra and illegal perquisites, the result being that 'the men had rather starve than buy them.' The original purpose of the supply was ' to avoyde nastie beastlyness by contynuall wearinge of one suite of clothes, and therebie boddilie diseases and unwholesome ill smells in every ship.' The whole of the clothes served out during the earlier years of the reign was not a quantity likely to have much improved the unpleasantly suggestive conditions of this passage.

In 1641 Northumberland, as lord high admiral, took the business in hand, and issued stringent regulations which forbade the sailor to purchase more than fifty shillings' worth a year, at fixed prices, and reduced the commission to sixpence in the pound, which was to be paid to the purser by the vendor. ${ }^{28}$ When, as rarely happened, a purser was honest, he seems to have been assaulted and persecuted by his captain, and bis position on board rendered unbearable. Perhapg the key to the situation is to be found in their petition of 1639 , when many of the pursers asked for incrensed pay, saying, - We know not how to subsist in our places without the continuance of what has ever been tolerated, or else the grant of a competent salary.' ‘s Corroborating this plea we have Holland's opinion that wages were too low, 'most of them being for want thereof necessitated . . . either to live knaves or die beggars, and sometimes both.' It was however a sign of the times that when in 1640, Thomas Smith, Northamberland's secretary, took $40 l$. for an appointment, he found himself exposed to the taunts of his equals and had to defend himself by asserting that he never bargained, but ' what men voluntarily give me my conscience assures me that I may take as mere gratuities.' It was still no crime but was reaching the stage which precedes legal condemnation. There is no trace of the sale of places during the Commonwealth, but the castom was reintrodaced with the other fashions of the Restoration.

Neither in their sense of honour nor in the extent of their professional knowledge did the navy captains of this generation

I Tbid. $\operatorname{ccc} 1 \times 1 x .36$.

Itrid. cecexsix. 83 . 
farourably impress their superiors. In Angust 1630 Mervyn, who was commanding in the Channel, wrote to Nicholas that he had captains who knew neither how to command nor how to obey, and a month later he requested that John Mennes should be given a ship, so that he might at least have one captain who had 'passed his a b c.' Men of such calibre nsually owed their position to, and obtrined other advantages from, court influence and family connexions. Of one man who received $3,000 l$. as his 3 per cent. commission on carrying treasure to Dunkirk we read, "You may see what a brother or friend in the bedchamber doth.' Another captain, his men said, was 'fearful in oaths,' plundered merchantmen, and threatened to kill any one who complained of him; his crew refused to sail, because 'for his blasphemous swearing they feared the ship would sink under them.' Others were questioned for beating officers and men, but in no case does any punishment appear to have followed. Another form of frand which came into existence now, and lasted till the present century, was the forging and uttering of seamen's tickets. The tickets were practically promises to pay wages due, and in the state of the royal treasury wore only saleable at a heavy discount. Not only did the captains and pursers forge tickets in the names of men who had never existed, but civilians carried on a brisk trade in such articles, and, when Crowe was navy treasurer, they were ' such good merchandize that a penniless wag made out a ticket for Ball, a dog . . . and sold it with a letter of attorney to a man who lodged seamen.' so

When the civil war commenced most of the non-combatant employés of the admiralty remained, like the officers and men, in the scrrice of the parliament, which took control by. means of committecs, whose members were constantly being changed. Subordinate to the parliamentary committee was a board called the commissioners of navy and customs, whose work was chicfly finuncial, and the functions of the principal officers, except the trcasurer's, were performed ly another body known ns the commissioncrs of the nary. The carl of Warwick was their lord high admiral, appointed in 1642, in place of Northumberland, and ho resigned in April 1645, to be again appointed on 29 May 1648,

\footnotetext{
to It must not, however, be supposed that naral morality was worse during the reigns of James and Churles than subscyucntly. Jeaving the cighteenth century out of consileration it was suid that at the berinning of this one the annual public loss from fraud and cmbezzlement ran intu millions, a sum which unag well havo almost irawn the shnrles of Mansell and hundreds of other pettifogging serenteenth-century navy thieves back to carth. I take the great difference to havo been that at the later liste, whether from higher principlo or want of opportanity, the combatant branches of the service were homest, the thoft and jobbory boing confined to tho admiralty, navy Imard, nal do:kyarl cstablishments. Lord St. Vincent said of the navy board that it was 'the curse of tho navy,' and the methods of the dockyards may be panged from the fact that whice the (pressent) 'Vietory' cost $07,400 l$. to build, 113,000l. were in fifteen fears expendod on her repairs. Of the $\Lambda$ dmiralty nothing need be said.
} 
when the news of the Rainsborow outbreak was received. In one matter the parliament found itself better off than the previous administration, for the question of timber had for years been a difficulty, the royal forests having deteriorated from various causes. Now, in spite of increased . requirements, it was obtained more easily by the process of seizing the timber on delinquents' estates. In 1632 a report was made on the condition of the forests, when that of Dean was said to be 'wasted and ruined,' the New Forest was ' so decayed' that there were not 2,000 servicesble trees in it; there were not more in Waltham Forest and hardly $\mathbf{4 0 0}$ in East Bere. ${ }^{31}$ Much of this wreck was due to lavish grants made by James and Charles to private individuals, and a further cause was the open theft which went on, sufficient wood to build ships being sometimes taken away without any attempt at concealment. Still; in 1639, there were 166,000 trees left in the Forest of Dean of an average value of twenty shillings a tree..$^{32}$

John Browne, who held the appointment of 'king's gunfounder' under James I, continued in that office during the whole of this reign. The price of ordnance in 1625 was from $18 l$. to $14 l$. a ton, and did not afterwards materially vary. Many complaints were made alout the excessive solidity and weight of naval guns, which caused much of the straining and rolling at sea, and they were so unnecessarily strong that when sold abroad the new owners rebored them for larger shot. In 1626 Browne was granted a reward of 200l. for casting lighter guns which had withstood a doulle proof; but, notwithstanding this encouragement, he, like every one else dealing with the crown, suffered in his purse. By June 1628 upwards of $11,000 l$. was due to him, and Evelyn, the powder contractor, had 2,400l. owing to him, and had refused to furnish anything more for three months past. Coke thereupon suggested to Buckingham that Evelyn should be compelled to resume his supplies, 'but till the censing of parliament holds it best not to urge him. too much,' which throws an interesting side light on general history. ${ }^{33}$, Notwithstanding these straits and the recuairements of his fleets, Charles did not neglect his glorious heritage in the crown jewels which were pawned to the Dutch, and Burlamacchi was directed to sell 4,000 tons of ordnance abroad and redeem the treasures. As an appropriate part of the transaction Browne found himself obliged to export in Dutch vessels, as they were provided with convoy. In 1692 . there were in store 81 brass and 147 iron pieces, presumably the reserve behind those in the ships and forts, and 207,000 round and 3,000 cross-bar shot. Stone shot are no longer mentioned. . $^{\text {T }}$ The allowance for a second-rate was three lists of powder, six cwt. of match, 970 round, 100 cross-bar, 70 double cross.

"State Papers, Doncstic, Charles I, cexxix. $114 . \quad$ "Ibill. cexlr. 19.

I Ilid. criii. 18. 
bar shot, and 2,000 rounds for small arms. ${ }^{35}$ The musket trade had been gained from us by Holland since the preceding reign, and now Sweden was underselling English founders of big gans; in 1694 Browne, in petitioning the king for payment, said that he had paid 1,200l. for a license to export ordnance, but that the Swedes were now selling at half-price. This Swedish manufacture was really worked by Dutch cepitalists, and within twenty years the price of English ordnance in the Low Countries had fallen from 86l. to 14l. a ton. For the proper equipment of the fleet, exclusire of castles and forts, 96 lasts of powder were required in 1635, bat in that year only 94 were in store for all purposes; between 1628 and 1685 there had been no powder in Southsea Castle, and doubtless many less important positions were equally ill furnished. Perhaps the crown could not supply the forts, beceuse too busy in private trade, the sale of gunpowder to merchants and others being a royal monopoly. A handsome profit was made on it, the cost being $7 \frac{1}{3} d$. per lb. and the selling price 18. 6d. In 1637 the year's gains on this article came to $14,786 l_{.}{ }^{36}$ The ordnance office had already obtained that evil pre-eminence in sloth and incapacity it has never since lost, and its situation in 1698 was that of the survejor sick, the clerk restrained of his liberty, one of his clerks absent, the clerk of the deliveries out of town and his clerk absent, the master gunner dead, the yeoman of the ordnance never present, nor any of the ganners attendant, and the stores for ordnance empty.' 37 Outcries, such as we have been also used to hear in this generation, against their delays in serving the ships with guns and ammunition, were loud and continuous, and in 1639 it was proposed to return to the original arrangement made by Henry VIII and allow the naval authorities to supply themselves with these necessaries. It is an illustration of the meditative and weighty caution with which official wisdom can be trusted to move onwerd from change to change that it was not until a few years ago that the alteration suggested in 1639 was made. Finally we read that 'the accountant nor other officers keep no books, and the ancient officers and clerks are averse to all new propositions which meet their inveterate frauds and defects.' ${ }^{38}$ The parliamentary leaders seen at first to have doubted how far Browne was to be trusted, since on 30 Dec. 1645 it was ordered that his works, which had been managed by deputies, should be given back to him.

Besides producing dangerous international friction the matter of saluting was a cover for theft and an excuse for waste at home. The lord high admiral seems to have been the only person whose reception was according to distinct forms, and for him the royal

- State Papers, Domeatic, Charles I, colrix. 67.

* Ibid. coclurvi. 160 and cccoxlii. 12.

- Ibid. cocrovii. 8T.

- Ibid. cocalrori. 115. 
standard was to fly at the main, yards to be manned, and on his approach within musket shot of the ship the trumpets were to cease and ' all who carry whistles are to whistle his welcome three times, and in the intervals the crew to cheer.' 89 Butler notices the fondness of the English for making a noise as a mark of deference, and the expenditure of powder in this way was described as the 'main excuse of gunners' frauds,' and as causing the waste of at least a thousand barrels of powder a year. Every one stood closely on his honour in the matter of salutes, and in 1681 Pennington was fired on from Pendennis Castle for not striking his flag. No occurrence was of too little consequence to be thus signalised; in one gunner's accounts we find: 'One faucon when the master's wife went ashore. ... One minion the master commanded to be shot off to a ship his father was in. . . . We shot two faucons in healths and three when Master Newton went ashore.' Of another ganner it was remarked: ' He cannot write, yet presents the account here enclosed, in which you see the king's powder spent in salutations of ketches and oyster boats. . . . I shall shortly send far greater and fouler examples of powder purloined by the last.' 10 The hired merchantmen in the royal pay had as much self-respect on this question as men-of-war, and saluted towns on entering and leaving harbour, the captain's brother, and 'the captain's friends for their farewell ' in orthodox service fashion. The large ones had, in some respects, the advantage of the smaller men-of-war, since the captain of one of the latter, in accoanting for his consumption of ammanition, said that ordinary traders 'scorned to strike to a whelp,' and he had to force them to their duty. The result of all this firing was that in the two and a half years ending on 80 June 1627 out of 653 lasts of powder issued to the various forts there had been 800 used in saluting. ${ }^{11}$ Nor were these proceedings devoid of danger, since the repeated orders that gans should be fired with blank charges were still disregarded, and there are several instances mentioned of persons on shore being struck from ressels saluting at sea. The admirals were equally sensitive about their dignity, and when Lindsey commanded the fleet of 1635 the question of his flags appeared to weigh most on his mind. On 1 May he complained that he had not enough flags and was not furnished with a standard ; the next day he repeats his wants, adding that he would like a kitchen ship, and a week afterwards he thinks himself ' $a$ little maimed,' still lacking the standard.

Among foreign powers the Dutch were the chief victims to the

- Batler's Dialogical Discourse, da. Of conrse the guns fould be going all the time. This form of reception eppears to hare been that given also to the king or to a gencral commanding an expedition.

- State Papers, Domestic, Charles I, liii. 40. Heydon to Nicholas.

4 Ibid. Ixxxviii. 27. 
requirements of maritime decorum, here complicated by the dispute about the dominion of the narrow seas. In July 1626 the captain of Deal Castle fired at a Dutchman which came into the roads with colours flying, and made the master pay ten shillings, the cost of the shot. 'In his report of the affair he says, "The rather did I it because I have heard it imputed that we have lost the jurisdiction of the narrow seas.' Six year's later a man-of-war having been sent to Calais to fetch the body of Sir Isaac Wake, her captain had the audacity to force the French to strike their colours to him. ${ }^{42}$ When Lindsey went to sea in 1635 his instructions ran that his 'principal care ' was to make foreign fleets perform their 'duty and homage,' and, if they refused, to make them answer for their 'ligh contempt.' ${ }^{3}$ Remembering the state of Lindsey's fleet, not only in the absence of the standard which he deplored go sadly, but in more urgent essentials, such as men, provisions, and stores, it was perhaps fortunate that Richelieu evaded the trial, and that the Dutch were content-for the time-to salute all day long if Charles so pleased. Northumberland, the next year, was told to insist on foreign ships yielding homage in Calais and other harbours if out of range of the forts. ${ }^{4}$ Wiser than his master, if he did more than look into the French ports he did nothing to provoke a collision. Moreover Northumberland may have felt that he was hardly in a situation to enforce compliance. Lindsey mentioned in his journal that in two days eleven ships lost masts and topmasts with only 'strong winds' blowing, but had not thought the circumstance deserved comment, although his vice-admiral, the old Elizabethan seaman Sir William Monson, was not so reticent. Northumberland's fleet was equally ill found, and on his return he charged the principal officers with giving him ships leaky and out of repair, fitter with defective masts and yards and bad cordage; some, he said, were too old to be worth repairing, and the new ones required girdling to make them fit for sea. ${ }^{45}$ What the earl thought of his men and stores has been already related. However, English captains continued to carry matters with a high hand, and, in 1637, Stradling meeting a Dutch squadron which did not salute with sufficient promptness, reported : 'The captain of the rear-admiral I have talien out of his ship and sent to Plymouth.' As time wore on the Dutch, seoing that Charles had enough to occupy his attention at home, became more independent, and in 1639 they were searching English ships and taking Spaniards out of them, a change from their former submissive attitude.

n Stato Papers, Domestic, Charles I, ccrx. 25. M. de Kermaingnnt (Le Droil des Gens Maritime . . a au Commencencent du XVIIe Sircle, Paris, 1892) snggests that the real origin of the English claim to the lordship of the narrow seas is to be found in the possession by our early lings of both shores of the Channel.

- Ibid. 2 Mey 1635. 1 Ibid. ecexvii. 102.

4 Ibid. cecsxxvi. 19 and ccerxxviii. 39. 
A precarious source of crown revenue was that obtained from the prize tenths. In the two years ending with May 1626 seventythree vessels had been taken and proceeded against in the admiralty court, and Bristol paid 7,604l. between 1628 and 1631. It was not until the civil war that the crew of a ship belonging to the state had any fixed proportion of the proceeds, but by a council order of October 1626 'a,competent reward' was to be given to the captors. On the other side seventy-seven ressels, of 100 tons and upwards, were taken by the enemy between 1625 and 1628, so that the balance of profit was hardly with us. In another paper we are told the, presumably net, proceeds from Spanish prizes between July 1626 and August 1639 came to $38,1581.88 .^{46}$ In October 1642 the parliament announced that henceforth one-third of the value of a prize was to be divided among officers and crew, in addition to wages. Its effect was undoubted, since from February 1643 to April 1649 prize goods were sold for $129,200 l$, and this must represent an enormously higher original value. ${ }^{77}$ However, out of this sum officers and men only got $14,465 l$., while the two collectors, Thomas Smith and John Hall, took 4,989l., Warwick 5,985l., and the expenses of storage, lading and unlading, \&c., were 17,000l. The delay and deductions in the payment of the thirds were among the chief causes of the trouble the Commonwealth experienced with the seamen in its earlier years, and in this account we see quite extraneous charges borne upon it. The treasnrer of the navy took 30,000l. from it, Augier, the parliamuntary agent in Paris, 610l., the secretary and usher of the committee of foreign affairs their salaries, and it had to meet various other items which would now go under the head of secret service money. The Datch system of rewards for ceptures was in working order long before ours and was liberal enough in amount. Privateers were allowed, beyond the value of the ship and goods taken, a state reward of from 8,000 to 30,000 guilders, the latter sum being given for any vessel of more than 100 lasts burden. If the enemy was sunk at sea instead of being brought into port, only half these sums were paid.

The following table, compiled from the ' Audit Office Declared Accounts' for the several years, gives the ordinary and extraordinary expenditure in round figures, as well as that of ship money, of which $1,028,702 l$. was demanded by writ, and 716,528l. was paid over to the navy treasurer. ${ }^{48}$ The estimates for the ordinary are for routine, naval, and dockyard work and the Channel squadron, and do not include the cost of the expeditions of the first three. years or of any of the later fleets. The amounts in the last column but one are those actually paid by Sir Wm. Russell out of tonnage

- Aud. Of. Decl. Accounts, 1699, 65.

47 Ibid. 1812, 448 \&

- State Papers, Domestic, Charles I, ceccsxrviii. 102. 
and poundage, anticipated revenue, and other sources. For instance, in 1625 he spent $170,000 l$, of which he received 119,000 l. from the exchequer, $40,000 l$. from tenths, fifteenths, and subsidies, and 'from the French king's agent' towards fitting ont the 'Vanguard' 4,800l.9 The last column gives the sums paid out of the ship-money receipts for the corresponding fleets; no doubt much of the balance went to clear off old debts, to pay for shipbuilding, as in the case of the 'Sovereign,' and other purposes :-

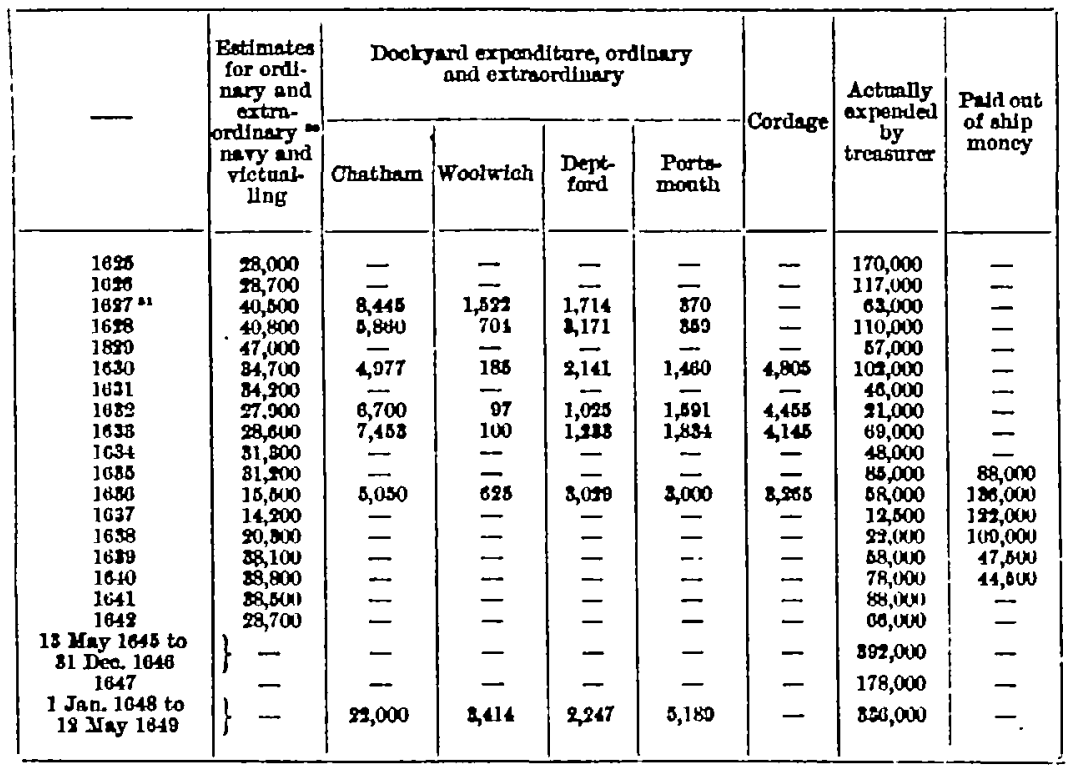

The disbursements during the civil war years by no means represented the naval expenses, there being always hundreds of thousands of pounds owing; the nuthorities, however, took care that the executive branches should be comparatively punctually paid, orners of hired ships and purveyors of stores being the principal snfferers by delay. Vane acted under an 'ordinance of both houses, of 8 Ang. 1642, concerning subsidy of tonnage and poundage,'and simply continued the forms and system used by his predecessors. ${ }^{58}$

- Pennington and his men were paid double wages 'out of the French king's monej8' (Aud. Off. Decl. Accotrits, 1698, 68), which throws their intense abhorrence of their work into still etronger reliel.

* For the distinction between 'ordinary ' and 'extraordinary' charges gee ExaIrsH Hrisonicer Rrview, vii. 492.

1 In this year the napy and ordnance offloes prere 251,000l. in arress (Stato Papers, lruxvi. 85).

" Few historical stadente admire Charles I, but even sach a ling as he is entitled to the justioe of posterity beyond that which he got from his contemporaries. Professor Hosmer (Life of Sir H. Vane the Youinger, p. 497) sajg that Vane ' had created the fleet out of nothing, had given it gons and men.' He appears to think 
Among the dockyards the most noticeable change is the steady increase in the use made of Portsmonth, while Woolwich was almost discarded, part of it being leased in 1633 to the East India Company

that a naval force, with its subsidiary manufactures and establishments, conld be created in a few jears, but, as a matter of fact, the parliament commenoed the struggle infinitely better equipped at sea than on land, and it was so powerful afloat that i did not find it necessery to begin bailding again till 1646, when the stress of the conflict was over. If Mr. Hosmer is referring to a later period, the statement is atill less accurate, eince the number of men-of-war had been increased and Vane had ceased to have any special connezion, except in conjunction with others, with naval affairs. Allowing for his narrow intelligence and vacillating temperament, Charles ahowed more persistence and continuity of design in the conduct of the navy than in any other of his regal daties; for, although relatively weaker as regards other powers, England, as far as ahips and dockyards were concerned, was stronger absolntely in 1642 than in 1625 . The ase made of the ship money showed that under no circumstances could Charles have been a great naval organiser; but he has at least a right to have it seid that he improved the materiel of the navy so far as hls limited riews and disastrons domestio policy permitted.

Returning to Vane, Mr. Hosmer says in one place (p. 148) that the post of treasurer was worth $80,000 l$, and in another (p. 376) 20,000 l. a year. What Mr. Hosmer's authority (G. Sikes, Tho Lifo and Death of Sir Henry Vare) really writes is, "The bare poundage, which in time of pence came to about 3,0002 , would have amonnted to about 20,000l. by the year during the war with Holland.' The ponndage in peace years never approached 8,000 ., and, as Vane ceased to bo treasurer in 1650 , and, from the date of his resignation, a lower acale of payment was adopted, the second pert of the calculation is obvioualy nothing to the purpose. Whether the reduction in the treasurer's commission was due to Vane or whether he resigned on aoconnt of it we have no evidence to show, nor do vague generalities help to clear the doubt. As bearing testimony to Vane's disinterestedness Mr. Hosmer quotes Sikes to the effect that he returned half his receipts, from the date of his appointment as sole treasarer, at the time of the self-denying ordinanoe. Unfortunately the accounts previous to 1645 are wanting and the question must remain open, but if the probability may be judged by general tendenoy it must be said to be extremely nnlikely, since, not content with his pay, he gave himsalf a commisaion of thirty shillings on every thousand pounds for portage, bags, Far, \&c, an addition which neither his predecessors nor successors received, and which, for the nineteen months ending on 81 Deo. 1650 , came to $1,005 l$. 16s. $2 d$. Moreorer he was treasurer from 8 Aug. 1642 till $B 1$ Dec. 1650, and during that time received in ponndage and salary for the five and a hslf years for which the acoonnts remain the sum of 19,620l. 1s. $10 \mathrm{~d}$. There is no sign in the andit offlce papers that he returned one penny of his legal dues, and, whoover alse had to wait, he seems to have paid himself liberally and punctually. Mir. Hosmer has only indirectly noticed that parliament, when Vane resigned, settled a retiring pension on him. Sikes says, 'some incongiderable matter without his seeking, was allotted to him by the parliament in lien thereot ' (i.e. of his place). The 'inconsiderable matter' was landed estate producing 1,200l a year. Beeing that he held his post for only seven and a half years, that daring that time he must have received at least $25,000 t_{\text {n }}$ and that all previous treasurens had boen, on cocasion, dismissed withont any suggestion of compensation, his disinterestedness may be questioned. When parliament roted Ireton an estate of $2,000 l$. a year he refused it on acconnt of the poverty of the conntry. And Bikes's version that it was ' without his seeking ' is not absolntely bejond doubt. On June 27, 1650, a petition of Vane's was referred to a committee to discuss how the treasarership was to be managed from Dec. 81 followIng, and 'also to consider what compensation is fit to be given to the petitioner out of that offlo or otherwise in consideration of his right in the said offloe.' It is no anjustifiable assumption to infer from this the possibility that the petition at any rate incladed a claim for compensation. Bikes, again, tells us that he cansed his subordinste Hutchingon to sacceed him, bat when, on 10 Oct. 1650, the motion was before 
at $100 l$. a year: ${ }^{32}$ It had long been pointed out that it frequently cost a fleet as much time and trouble to get round from the Thames to Portsmouth as from that place to the Mediterranean, and under Buckingham's administration it came into favour as a rendezvous for the ships prepared for service. It possessed a graving, but no dry dock, and in 1627 the duke caused estimates to be prepared for the construction of a double dock, but his death deferred the question. ${ }^{54}$ In 1630 Pett, Sir Thos. Aylesbury, and others were sent down to report on its capabilities, and they recommended that the men-of-war should ride in Farebam creek, at the head of the harbour, about a mile and a half from Porchester and two miles from the then dockyard, a proposal which was adopted. 'They did not advise the making of a dry dock, thinking the rise and fall of the tide too little, and 'there is no use of any there;' ${ }^{35}$ but personal interests were also in the way, the comfort and pecuniary advantages of the shipwrights being bound up with the Thames and Medway yards. From this date, however, a few ships were always stationed at Portsmouth, but it was not until January 1638 that a master shipwright was ordered to reside there permanently ; before that time the shipwrights had taken the duty in turns, and the absence of a dry dock, although several times intended to have been commenced, was still causing inconvenience and expense. Russell complained that ' his majesty cannot have a pennyworth of work there done under tropence, in respect the king's yard and the ships be so far asunder for transporting materials.' The dockyard consisted chiefly of storehouses, and orders had been given that all private-houses near them were to be tiled instead of thatched, they baving been once already burnt down during the reign of Elizabeth. It is difficult to say what extent of ground belonged to the crown at this time. The official plan now existing gives the size of the dockyard when first formed by Henry VIII at 8 acres 1 rood. The natural suspicion with which one regards an official statement, whatever its date in the centuries, was here intensified by the exactness of the measurement and the fact that the admiralty

the house that the 'question be now pat' whether Hatohinson's appointment should be made, Vane was one of the tellers for the 'Noes' and was benten by 27 to 18 . This was immediátely followed by Hutchinson's nomination pithout a division. The incidents of Hutchinson's officinl career imply a much atronger and more lasting influence than that of Vane, but the only imporfance of the question is as affecting the trustworthiness of the latter's seventeenth century biographer. Mr. Hosmer, like all other writers on Vane, appears to quote Sikes with implicit faith, bot the man oridently wrote only loosely and generally, making up in enthusiasm what he lacked in exactness; c.g. ' In the beginning of that expensive war he resigned the treasurership of the navy.' Hutahingon succeeded him from 1 Jan. 1650-1, and war with Holland did not occur till June 1652. There is nothing to show that Vane was not an honest administrator, but his party, fortunately, prodaced many others equally trustworthy.

is Add. MSS. 9802, 1. 42.

of Ibid. 9297, f. 75 .

-s State Papers, Domiestic, Charles I, clsxiii. 32. 
either do not know or will not say by what means it is obtained. Those suspicions were confirmed by finding-so far is the official date of 1540 from being correct-that storehouses and a dry dock, large enough to take the 'Regent,' existed in 1507. In 1523 Henry VIII added other buildings and constructed a dock capable of receiving the 'Henry Grace de Dieu.' Another cause of hesitation in the adoption of Portsmouth as a permanent naval station was the diverse opinions expressed as to the existence of the Teredo navalis in the harbour. This maritime pest, probably brought into northern waters from the tropics during Elizabeth's reign, played havoc with ships mostly unsheathed, and whose sheathing, when it did exist, was ill adapted to resist its rarages. In 1630 the chief shipwrights reported that ' no worm destractive to ships is bred in Portsmouth harbour;' five years later some of the same men turned round with, "We positively conclade that there is a worm in that harbour.' 'The decision was still postponed till, in September 1645, a number of shipwrights were sent down, and it thenceforward rapidly grew in naval importance, although the dry dock, so often ordered, was not commenced till 1656 .

Chatham had for nearly a century been the first of English dockyards, and in 1634 contained seventy-five acres, held on a lense granted for 100 years, from 1618, by Robt. Barker, lord of the manor of Chatham. ${ }^{56}$ In March 1627 Coke, at the request of the king of Denmark, sent a Dane named Andersen there, with a letter of recommendation to the officisls, desiring them to explain to him their methods of work. The request was complimentary, but Andersen could hardly have been very favourably impressed by all he saw and heard. The dockyard service was as much disorganised as the rest of the administration; the 'Assarance' had recently been repaired only by the expedient of selling fifty-four guns to pay the expenses, ${ }^{57}$ and $7,740 l$. was owing to the shipwrights and shipkeepers there, nearly eighteen months' wages being over-due.ss They had of course freely petitioned, but ' a letter to persuade the workmen to go on cheerfully' had quieted them for the time. One explanation of their patience may be found in the existence of $n$ rule under which persons in the naval departments could not be proceeded against legally until permission was given by the authorities. Just before Andersen's visit work had been at a standstill for want of materials to the value of $400 l$., which the government could not obtain on credit, and, in April, the workmen still had fifteen months' pay due. Both the commissioners and chief officers confessed their inability in face of these difficulties, since if the men were discharged they came clamouring and threatening daily for their wages, and if kept on there were not sufficient stores

- State Papers, Domestic, Charles I, cclrxix. 20.

s7 Tbid. ccxlv. 49, January 1627.

s* Ibid. 1. 45. 
for them to work with. ${ }^{59}$ Matters did not improve, and in 1629 Edisbury pointed out that, in addition to all this, great waste and theft existed, many families living in the dockyards, and cabins and other parts of ships being daily ransacked, and the materials stolen or used for fire wood, "every one almost being director of his own work for want of some able, understanding man to regulate the inferiors, ag it was while the commissioners had the government.' 10 This handsome testimonial to the merits of the commissioners, lately relieved, may be considered impartial, for the interests of Edisbury, then paymaster, but shortly to be himself a principal officer, were bound ap with those of the officers. Another writer tells us that the master shipwrights rated their subordinates according to favour, and that they themselves were sometimes absent for one or two months at the time at their own private yards. ${ }^{61}$ In thirteen years' experience he had never known any inferior suffer for delinquency, ' although he had been convicted of divers stealths.' At the most they were suspended, and then restored, and the entries in the State Papers bear out Holland's assertions. He also tells us that Fridays, being the Rochester market days, were kept as a general holiday in the dockyard; the expenditure on ornamental carving and painting had become four times as great as formerly, because the amount was left to the master shipwrights who refused to be outdone by each other; if work was done by contract, a bill was usually sent in for 'overworkes' which exceeded the original contract amount, and, as a result, the shipwrights' houses were 'fitter for knights than men of their quality.' These houses had back doors opening into the dockyard-for obvious purposes, the writer hints.

The almost incredible financial straits of the treasury may be measured by the fact that some storehouses in Chatham yard having been damaged by a storm in January 1630 the money necessary for the repairs-only 20l.-had to be obtained by selling old cordage. ${ }^{68}$ Large sums, however, were at vorious times expended on maintaining, improving, and eniarging the yards. In 1629 there was spent 2,197l. on Portsmouth, Deptford, and Chatham, ${ }^{63}$ and in 1694 there was a further estimate of 2,445l. for the same places for additions subsequently carried out, one of them being a brick wall round the new dock at Chatham. The barricade across the Medway at Upnor, although it had been allowed to become almost useless, was still nominally maintained. It must have been an expensive defence, since the estimate in 1685 for another, made like the earlier ones of masts, came to $2,305 l$., besides involving a

- Ibid. crxrviii. 66.

- Ibid. crliii. 87 .

a J. Holland, Discourse of the Navy. 4 Add. MS8. $9801,1.185$.

- Egerton M8S. 2541, t. 128. Deptiond was chiefly used for bailding, and Chatham for repairing. 
yearly outlay of $624 l$. to keep it in good order. An iron chain weighing twenty-eight tons, and held by eleven anchors, was recommended in its place, as costing only 1,500l. ${ }^{\text {G. }}$ The long parliament further enlarged the dockyards, and cared for the shipwrights spiritually as well as physically. In 1644 they ordered that a lecture should be delivered at Deptford every Wednesday morning on 'saving truthe,' and the time thus occupied was not to be deducted from the men's pay.

In 1637 the stores at Woolwich, Deptford, Chatham, Portsmouth, and on board the ships in harbour comprised 1,446 tons of cables and cordage, 221 tons of anchors, 79 lasts of tar, sails made up to the value of $4,500 l$., canvas not made up to $5,000 l$., $167 \mathrm{com}$ passes, 2,296 hammocks, 520 masts, 1,200 spars, 3,694 loads. of timber, and 332,000 tree-nails. ${ }^{a s}$ This was in the full flush of the ship-money receipts, yet both cordage and timber are far below the minimum considered necessary by either principal officers or commissioners. As in later years ships lying up were dismantled, and in 1681 the lords of the admiralty ordered that, instead of sails and rigging being kept in a confused heap at Chatham, a room, with the ship's name painted on the door, should be provided for the belongings of each vessel. In 1697 Hildebrand Prason died, he and his father having been sail-makers to the navy for sixty years. Edisbury then tried, but in vain, to persuade the lords commissioners to have the sails made at Chatham and save a fifth of their cost. So far from undertaking fresh responsibilities they desired to transfer some of those they already bore. They were at the time negotiating with Russell about an offer he had made to provide the squadron for the narrow seas by contract at $3 l$. a man per month, that rate to cover all expenses except those of repairs to the vessels. ${ }^{66}$ They were to be nine months out of the twelve at sea, and donbtless Russell saw his way to a profit, bat the proposal mas not carried into effect. There were few naval improvements introduced under Charles. Deck ring-bolts for the lashing of ordnance were first supplied in $1628 ;^{67}$ staysails came into use early in the reign, one of the whelps having two in 1639, and in 1639 there were forty in store at Portsmouth, but they seem to have been only fitted to the smaller classes of ships.

However badly off fleets might be in material necessaries, they ahould have been well furnished with the æsthetic refreshment of flags, judging from the number in store. In $16261,280 l$. was spent in providing them, and in January 1627 there were 415 of various kinds to be had at Chatham alone, and however low in the fature might fall the reserves of powder every care was taken that the men should not lack this solace. A proclamation was issued on 5 May

\footnotetext{
- State Papers, Domestic, Charles I, cccil. 27. - Ibid. cecliii. \& 67.

* Ibid. cocxlvii. 85. $\quad$ Ibid. xlviii. January 20.
} 
1634 commanding that English and Scotch merchantmen were no longer to fly the union flag of St. George's and St. Andrew's crosses, but to each keep to its own national cross, men-of-war alone flying the union. The parliamentary committees were just as fond of flags, for in the sixteen months ending with November 1646 they spent 1,178l. on these articles, while sailors' hammocks for the same period cost only $777 l$. For 1647 their bill for flags was $567 l$. and for hammocks 307l. In Feburary 1649 the parliament ordered that men-of-war ehould carry a St. George's cross on a white ground, similar to the present admiral's flag, which, although the St. George's cross had been in general use for many centuries, may be considered to be the beginning of the present naval ensign in its special form. ${ }^{68}$ dates :-

The following prices were paid for naval necessaries at parious

Cordage (1625), 28l. 188. 4d. a ton.

" (1620), 82l. a ton.

" (1681), B0l. "

"(1640), ," ,

Tear (1681), 8l. 10. a lest.

" (1685), 10l. a last.

Rosin (1681), 18l. a ton.

Train oil (1681), 20l. a ton.

Crooked and straight timber (1681), 1 . 108. a load.

Knee timber (1681), 2l. 10s. a load.

Elm " " 12. Gs. , " (1640), 1l.12. ", "plank (1626), 1l. 18s. " Oak " " 2l. 2s. " " " (1640), 3l. 11s. " French canves (1685), 22l. a bale. Ipswich " (1626), 1l. 6s. a bolt. " " (1695), 1l.108. "

Powder (1627), 5l. a barrel.

" (1646), 4l. 10. a barrel.
Round shot (1627), 11l. a ton. Musket shot (1627), 14l. a ton. Hammocks (1625), 2s. each. " (1642), 2s. 7d. each.

Anchors (1626), $1 l$ 10s. to $2 l$. per owt. " (1681), $2 L$ per cwt. , (1640), 11. 18s. per cwt.

Beer (1685), 28s. to 34s. the tan. " (1640), 38s, the tun.

Beef in 4-lb. pieces (1685), 9d. and 10d. the piece.

Pork in 2-lb. pieces (1695), 5d. and $6 d$. the piece.

Codfish (1635), 4l. 88. the cwt.

Biscuit " 18s. and 14s. the cwt.

Seamen's clothes (1628) : ${ }^{\infty}$

Shirts, 8s. 4d. each; caps, 2s. each ; cotton breeches, 20. 8d. each; stockings, 18. $4 d$. a pair; eanvas suits, 6. each ; cotton waistcoats, Bs. each.

\section{OpPENhen.}

- It is possible, too, that the present navy button and cap badge may be traced back to the parliamentary regime. Northamberland's seal consisted merely of his arms with a background of sea and ships, and although earlier lord admirals-Bonthampton, Lincoln, and Buckingham-had used the anchor, none of them had combined the coronet, anchor, and wreath. Warwick's was one which differs only in the relative proportions of the details from the batton and badge now in use, except that the anchor is now fouled. If it is only a coincidence it is a ourious one. Popham, Blake, and Deane employed a modiflcation of Warwick's seal, omitting the crown, and then the navy office started one of its own, consisting of three anchors, a large centre one with 2 smaller on each side, and 'The Seale of the Navye Office' round the edge, so that the device selected by Warwick seems, in one form or another, to have been soon widely ueed and continued.

- These prices were paid by the government; the cost to the sailor depended on the honesty of many intermediaries. 